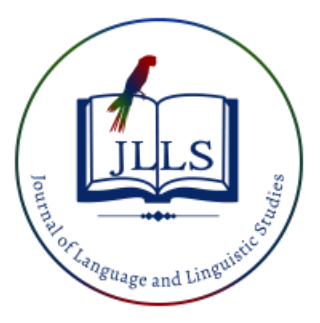

Available online at www.jlls.org

JOURNAL OF LANGUAGE AND LINGUISTIC STUDIES

ISSN: 1305-578X

Journal of Language and Linguistic Studies, 17(1), 301-308; 2021

\title{
Lexical meaning in Albanian language textbooks of pre-university education
}

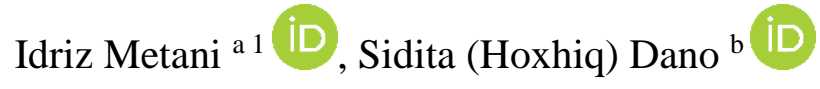 \\ ${ }^{a}$ University of Tirana, Albania \\ ${ }^{b}$ University of Tirana, Albania
}

\section{APA Citation:}

Meta, I., \& Dano, S.H. (2021). Lexical meaning in Albanian language textbooks of pre-university education. Journal of Language and Linguistic Studies, 17(1), 301-308. Doi: 10.52462/jlls.18

Submission Date: 08/01/2021

Acceptance Date: 12/03/2021

\begin{abstract}
Lexical meaning, as an important and essential aspect of the word, has long attracted the attention of scholars, who, in trying to know its nature, have sometimes mystified it by seeing it as an inexplicable thing and sometimes simplified it, equating it with the function of the word, with the concept, even with the reali iii itself that it signifies. Each meaning is explained separately, but keeping in mind the other meanings of the word, when it is polysemantic. The purpose of explaining meaning is to connect us with realie or something ${ }^{\text {iii }}$ of the reality that the word signifies in that sense, to identify and distinguish it intact from other realities similar to it.

In addition to the common semantic components, some differentiating semantic components are given that serve to distinguish the meanings of the respective words.

By thoroughly analyzing the corpus of words unknown to students present in today's Albanian language textbooks of pre-university education, our article aims to provide an almost complete picture of the typology of explaining language units unknown to students, as it turns out in the textbooks we are talking about while giving some methodological recommendations to improve the work with students' vocabulary in the future. In general, we can say from the beginning that textbook compilers, in order to explain language units unknown to students, have used at least four types of explanations: descriptive explanation, definition explanation, paraphrasing explanation and synonymous explanation, which will be discussed in more detail in this article.
\end{abstract}

Keywords: lexical meaning, realie, textbooks, explanations, language units

\section{Introduction}

The need to explain the meanings of words arises, not only in lexicography when compiling dictionaries, but also when we learn our mother tongue at school or when we learn a foreign language. An important component of this lesson is the enrichment of students' vocabulary, therefore in today's Albanian language textbooks ${ }^{\mathrm{iv}}$ of Albanian pre-university education after each literary ${ }^{\mathrm{v}}$ or nonliterary ${ }^{\mathrm{vi}}$ some linguistic units are given (words, syntagms of phraseological expressions), averagely four for each part, which, according to the authors, make up the unknown vocabulary of students, which in a

\footnotetext{
1 Corresponding author.

E-mail address: idrizmetani@yahoo.com
} 
certain time of the class, in the didactics of teaching and learning of Albanian language, is known as "working with the vocabulary », becomes a discussion topic, in order to make the students learn better the semantic structure of Albanian lexicon, to better organize the thoughts (concepts) with different varieties of speech, to make it more various and rich,

The present article, with the object of study, the typology of explaining words unknown to students in today's textbooks of the Albanian language of pre-university education, i.e, in the textbooks certified by the Albanian Ministry of Education that began to be used in school since 2015, aims to examine the corpus of linguistic units considered unfamiliar to students by textbook authors in three main respects: first, in terms of lexicographic typology to see the explanation provided to students by the textbooks we are talking about ; second, in terms of content to briefly analyze the lexical richness that includes vocabulary that is explained as unfamiliar to students of pre-university education ; and thirdly in terms of lexico-grammar to look at the lexical classes to which the language units that are known to students are unknown by the compilers of texts.

\subsection{Literature review}

What is important to be mentioned here is the fact that after some reformation made by the Ministry of Education, there has been a change in the curricula of Albanian Language Grammar and Literature in the pre-university system. Now students have one book, which includes both texts. Most of the studies have been focused mostly on this aspect and on comparing different school texts. Thus, there is a lack of study in the field of lexical meaning, only some authors have mentioned the issue without focusing on the main topic, such as Tomorr Plangarica, Simon Pepa and Bora Logu, as well as

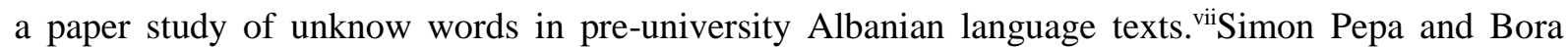
Logu talking about the development of vocabulary as a basic component in students' discourse (Pepa. S - Logu. B, 1998) claim that explaining the meanings of unfamiliar words is one of the most important tasks, not only teaching the Albanian language, but of the whole teaching process in school. ${ }^{\text {viii }}$

\subsection{Research questions}

As far as we know so far, the typology of explaining unfamiliar words to students in Albanian language textbooks of pre-university education has not been the subject of any special work, meanwhile, for students' vocabulary and lexical richness of textbooks has been written here and there in a particular article, sometimes directly (Plangarica, 1998) sometimes in the bay of other articles, ie indirectly.

Also, it is already known that in the Albanian language we do not yet have school lexicography, i.e. school vocabularies are missing, so, in these circumstances, our article, with the analysis it makes of the corpus of language units unknown to students and the recommendations it gives, can replace this shortage by helping teachers and students to understand the typology of explanation, the requirements for a good explanation as well as the structure of the explanation of the meaning of the words (Lubishtani, 2019; Berisha, 2019).

\section{Method}

Studies in the field of semantics (John Lyons, 1977) have already proved that understanding as a basic semantic unit is a structure constructed of minimal semantic units, which were first called semantic components and, later, according to various authors (Katz- Fodor, 1963; Chafe, 1967; Prieto, 1968) of the linguistic directions they follow: semantic component, seme, semantic feature, etc., while 
the method by which these components are discovered within the structure of meaning was called the method of component analysis ( EA Nida, 1949). Through this method, which is widely used in our article in attachment and with the method of comparison and description, we have been able to penetrate into the semantic structures of words unknown to students, present, as we have said, in the texts for which we are talking, to analyze the components of the meanings of those words that the compilers of today textbooks of the Albanian language have explained as words unknown to students.

\subsection{Analysis}

Before giving an almost complete overview of the typology of explaining unfamiliar words to students, as it appears in the texts analyzed by us, we are taking a quick look at the lexical richness carried by the glossary of unfamiliar words for the students present in today's textbooks of the Albanian language of pre-university education, which we are presenting through the Table 1.

Table 1. Linguistic units unknown to the students

\begin{tabular}{|l|l|l|c|l|l|}
\hline $\mathrm{Nr}$ & Text & words & phraseologies & syntagma & Total \\
\hline 1 & Gjuha shqipe 2 & 78 & 12 & 22 & 112 \\
\hline 2 & Gjuha shqipe 3 & 81 & 13 & 21 & 115 \\
\hline 3 & Gjuha shqipe 4 & 106 & 17 & 12 & 135 \\
\hline 4 & Gjuha shqipe 5 & 134 & 7 & 11 & 152 \\
\hline 5 & Gjuha shqipe 6 & 115 & 20 & 5 & 140 \\
\hline 6 & Gjuha shqipe 7 & 162 & 10 & 7 & 179 \\
\hline 7 & Gjuha shqipe 8 & 76 & 2 & 1 & 79 \\
\hline 8 & Gjuha shqipe 9 & 81 & 1 & 0 & 82 \\
\hline
\end{tabular}

From the data of the above table, but also from our direct observations in the mentioned texts, it appears that this wealth consists first, of lexical words (Broncart, 1991), i.e of semantically complete words that have a genuine lexical meaning., such as ashef, latoj, stërpikë, shortare, zezonë etc; secondly, phraseological units (idioms), such as $i$ jap faqe, mori faqe, i përpoqi fjalët (me dikë), është flakë e zjarr, imban veshët hapur etc; thirdly, from syntagmas, mainly in figurative structures (I. Tamba-Meez, 1981), or as they are called differently, extraordinary relation of words, such as: adresat-shpendë të largët, babai-heshtje që del, agim i trëndafiltë, alfabet i përgjakur, baladat flenë, balona e hënës, fëmijët-kolombë të ardhshëm, gjethet-zogj të vrarë, hëna rrokulliset etc.

Here it is interesting to note that in the midst of metaphorical syntagms are given many of them, which, in typological terms, are classified as semantic equations. The value of semantic equations is carried by those metaphorical syntagms, which place the equal sign between two words that, in fact, have different meanings (I. Metani, 2006), such as: ballkani-Promete, Ballkani-plak gërnjar, Ballkanidjalë i fuqishëm, deti-zog i kaltër, hëna-pus i tharë, heshtja-mur i ftohtë, jeta-dafinë me katër stinët të gjelbëra, koha-ulkonjë e vjetër, mosha-gaforre që shkon prapa, nata-këmishë e zezë, poetët-lumenj të turbullt, etc. (Balkans-Prometheus, Balkans-grumpy old man, Balkans-mighty boy, sea-blue bird, moon-dried well, silence-cold wall, life-laurel with four green seasons, time-old owl, age-crab that goes backwards, night-black shirt, poets-turbulent rivers etc.)

These types of equations, which are present, especially in poetic texts, have a great impact on the student, because he, the student, being faced with such equations, where words are not really equivalents, tries to add and descend themselves into their content to achieve balance between words. 
The beauty and strength of these semantic equations lies precisely in the identification of two different contents, which, being highlighted, affect each other mutually tending to approach semantically.

If we look at the lexicon unknown to students present in the new Albanian language textbooks of Albanian pre-university education in terms of lexico-grammar, we will notice that it includes mainly three classes of words: nouns, which occupy about $60 \%$ of it (acar, admiral, adhurim, afsh, ag, agoni, ajodhimë, akuarium, album, amanet, ambicie, ankth, apologji, ar, arap, arenë, arkiv, asqer, at, antetat, aureolë, autograph, autoritet, avdes, babagjysh, bagazh, bamirësi, bar, barbar, beden, begati, bekim, beretë, bicak, bigë, bjeshkë, bokë, boshtërbrengë, brockull, bruz, bucelë, bujtinë byk, cak, cekëtinë, celluloid etj., foljet (adaptohem, admiroj, adhuroj, avitem, bares, bekoj, bëlbëzoj, bllokoj, bluaj, brohoras, capëlej, capitem, cerkat, davaritem, dekompozohet, depërtoj, dergjem, dihat etj.) and adjectives ( $i$ amullt, $i$ argjendtë, $i$ artë, automatike, $i$ befasuar, $i$ bekuar, $i$ bleruar, $i$ bredhur, brutal, $i$ cmeritur, i denjë, i dëlirë, i devotshëm, ifamshëm etj.) which takes 22 of $18 \%$ of this lexicon.

From the careful and thorough examination of the typology of explaining words unknown to students in today's Albanian language textbooks of Albanian pre-university education, we note that it includes four main types of explanations, which, as we stated above, will be given through the following table:

Table 2. Typology of words unknown to students with paraphrase in explanation and definition in synonymy

\begin{tabular}{|l|l|c|c|c|c|}
\hline Nr. & Text & & & & \\
\hline 1 & Gjuha shqipe 2 & 13 & 57 & 12 & 11 \\
\hline 2 & Gjuha shqipe 3 & 4 & 41 & 8 & 24 \\
\hline 3 & Gjuha shqipe 4 & 9 & 66 & 11 & 43 \\
\hline 4 & Gjuha shqipe 5 & 20 & 57 & 20 & 43 \\
\hline 5 & Gjuha shqipe 6 & 14 & 49 & 11 & 34 \\
\hline 6 & Gjuha shqipe 7 & 19 & 77 & 6 & 33 \\
\hline 7 & Gjuha shqipe 8 & 6 & 24 & 35 & \\
\hline 8 & Gjuha shqipe 9 & 6 & & & 46 \\
\hline
\end{tabular}

As can be seen from the data in the table ${ }^{\mathrm{ix}}$, the compilers of Albanian language textbooks for most of the unknown words have used descriptive explanation, which is followed by synonymous explanation, while the other two types of explanation (with paraphrasing and with definition) are used less.

a) descriptive explanation is used regularly for lexical meanings that have real references with obvious features that are perceived (grasped) by our sense organs, i.e., for the concrete lexicon.

This type of explanation reflects the relevant indicators of reality to which the word refers or describes reality according to these indicators, which should be well known by teachers and even students of pre-university education in order for them to scientifically explain the meanings of words, so here we are stopping a little longer to say that realities differ from each other because they carry some essential features that are known in lexical semantics as its indicators and that are expressed linguistically through the semantic components present in the structure of lexical meanings of words. The indicators of realities are several: a) the indicator of the closest class to which realia belongs; eg. the table is the furniture, the apple is the fruit tree, etc., b) the indicator of the substance of which reality is composed; eg. the cloth is made of silk, etc., c) the indicator of the construction of reality; eg. the house has walls, roof and partitions in rooms, etc., d) the indicator of the features of reality; eg. the snow is white, etc., dh) the indicator of the function or use of reality; eg. the ship is used for water 
navigation, etc., e) the reality environment indicator; eg. fish grow in the sea, river lake, etc., f) indicator of the history of birth and development of reality; eg. Classical structuralism in linguistics was born in the early twentieth century, etc. We will provide some examples: lule mëngjesi (morning flower) bot. "bimë zbukuruese kacavjerrëse, me gjethe si zemër, me lule të bardha, të kaltra ose ngyrë vjollcë dhe me njolla e me vija të ndryshme, të cilat rrinë të çelura vetëm në mëngjes ose në ditë pa diell" (creeping ornamental plants, with heart-shaped leaves, with white, blue or purple flowers and with various spots and stripes, which stay open only in the morning or on a sunless day), mjellmë zool. (swan) "shpend $i$ madh uji, me qafë të gjatë e të lakueshme, me krahë të gjerë, , mependë zakonisht të bardha e të shkëlqyeshme si bora, që shtegëton" (large waterfowl, with long, curved necks, broad wings, with feathers usually white and shining like snow, migrating)

b) synonymous explanation has been used especially for words or meanings of words limited in use, such as, say, provincial or dialectal words and meanings, obsolete words and those of simple speech, or lexical borrowings that can be replaced by words and Albanian expressions e.g. kumpira dialectism for potatoes or molla te arta, dialectism for tomato; bajloz old form for ambassador; inaugurate etc. This is how many word-formation variants that have the same meaning as, for example, are explained in the texts we are talking about, such as, thatiq-i thatë, thatim (dry, very thin), frikanac-frikacak (coward)etc.;

c) paraphrasing explanation has been used by the authors of Albanian language texts to explain the linguistic units belonging to the general and abstract lexicon. These linguistic units are few in number so the paraphrasing explanation does not take up much space in the texts we are talking about, it is used when we give the lexical meaning with some other familiar words, which actually decompose it according to elements that make it up, separating, by the method of component analysis some of the semantic components to grasp it better, e.g. disinfect (destroy or destroy with chemicals and special tools harmful microorganisms (microbes, etc.) or their carriers (insects, etc.); I clean a place or an object (clothes, etc.) from germs or poisonous substances ", I burn something a little on the outside and on the surface, I burn it over a flame or in a fire; burn "etc.

d) by definition explanation is regularly used for terminological meanings. It contains linguistically expressed indications of realies that are essential to its nature, eg. brom, -i m "chemical element, nonmetallic, liquid, heavy and poisonous, whose vapors are dark in color and have a strong and heavy odor".

In addition to the explanations mentioned above, in the current textbooks of the Albanian language are used less and especially in the lower grades of pre-university education, two other types of explanations: explanation with illustration and mixed explanation (with words and illustration at the same time). We find it right to take the position taken by the authors of the textbooks in question to explain with these two types of explanations words and expressions that belong mainly to the abstract lexicon, which young students find difficult to perceive (grasp) it mentally. or intellectually.

\section{Discussion and conclusion}

By looking at the linguistic units that are explained as unfamiliar to students in the current Albanian language textbooks of pre-university education, some more general conclusions can be drawn and some methodological recommendations can be given to improve the work with the unknown lexicon to students in the future:

First, the number of linguistic units for each text averages to the figure 150, most of which are lexical units related to the specific lexicon, while idioms, i.e., phraseological expressions from the point of view of the semantic bovine are in the majority of verbs, and syntagms higher frequency metaphors are those with noun + adjective structure; b) lexical units are generally explained in their 
first sense, i.e., in the initial historical sense in which they entered the language and lived in it, few words are explained in their figurative sense.

Secondly, in general, the lexicographical model provided by the Albanian language textbooks of Albanian pre-university education in explaining words unknown to students is close to that used in national explanatory dictionaries, but meanwhile the lexicographical typology of this codex or lexicographic model in many cases it is violated when the explanation does not fully correspond to the meaning in lexical-grammatical terms, in other words, the meaning of the name is explained by a wording that has adjective value and vice versa, the meaning of the adjective is explained by a formula that has noun value, e.g. the name skërfyell in the text of the Albanian language of the third grade is explained with the formulation: "very long and thin", while the long-awaited adjective in the same text is explained with the noun formula: "something we look forward to" etc.

Third, in a considerable number of lexemes the explanation does not contain the necessary elements to identify the reality that is signified by the word. Moreover, in such words, as the first element of the explanation, there is no semaphore or semantic component that linguistically expresses the indicator of the nearest class where the reality marked by the word belongs, but an ingredient is placed that does not identify the object or phenomenon at all. is marked by the lexeme e.g. The abstract noun anxiety is explained by the part "anxiety", when it is known that this name is identified with the part "heavy dream" in its first meaning and with the other ingredient "oppressive or oppressive feeling" in the second sense. The explanation of words unknown to students in the current Albanian language textbooks of Albanian pre-university education, should not be simply and only a copy of the model given by the explanatory dictionaries of Albanian, he, of course, that, in the conditions when, as we have said previously, age dictionaries are missing, will be based on this model, but, meanwhile, should be shorter and thicker (condensed) and, at the same time, clearer and more easily accessible to students. Thus e.g. the explanation of the paradigmatic group of adjectives with the meaning of the feature according to the subject, can start with the formulation: "which consists of...", "which is of...", "which is made of...", the word comes florinjtë (i, e) (golden) "that it is made of gold ", gold watch; while the explanation of the meanings of the possessive adjectives can start with formulations such as, "that does...", "that has..." that is... "etc. eg. verdhë (i, e) (yellow) "having the color of gold, straw, sulfur or ripe lemon e yellow jacket", meanwhile, the abstract names with the meaning of quality can be explained by starting the formulation with the neutral name "Being Duke "and listing after him the surname from which the abstract quality name derives e.g. happiness "being happy" etc.

Fourth, working with students' vocabulary in general (including the explanation of unfamiliar words) requires from teachers who teach the subject of Albanian language in pre-university education, not only constant attention and care, but, first of all, some knowledge genuine lexicographical, which, as it appears from our direct observations, in a considerable number of teachers, are insufficient. In order to equip teachers with such knowledge, we think that it is necessary firstly a special qualification of teachers with experienced lexicographers and secondly, the time has come that until school dictionaries are published, the dictionary of today's Albanian language should be treated as textbook, which means all students and teachers who teach the Albanian language in Albanian pre-university education are provided with it.

\section{References}

Broncart, I. P (1991), Dictionnaire de psychologie

Chafe, L. (1967), Language as Symbolization, "Language”, 43(1). 
Katz, J. Fodor, J (1963), The Structure of a Semantic Theory, "Language”, 39

Metani, I. (2006), Vështrimi mbi gjuhën e figurshme të poezisë së Xhevahir Spahiut, "Studime filologjike", $3-4$, Tiranë

Nida, E. A. (1949), Morphology: the Descriptive Analysis of Words.

Berisha, A., \& Binaj, K. (2019). Do + subjunctive, future reference and modality in Albanian. Journal of Language and Linguistic Studies, 15(4), 1426-1435. Doi: 10.17263/jlls.668544

Plangarica, T. (1998), Formimi gjuhësor i fëmijëve, psikolinguistika dhe pasuria leksikore e teksteve shkollore, Studime shqiptare, 10, Shkodër; Pasuria leksikore në disa tekste shkollore, III, IV të shkollës tetëvjeçare, Gjuha jonë, 1990; Aspekte të gjuhës së zbatuar, Elbasan, 1998

Prieto, L. (1964) Principes de neologie: fondements de la theorie fonctionnelle du signifie.

Lubishtani, M. (2019). Contrastive analysis of the semantic relations of connectors in argumentative texts in English and Albanian. Journal of Language and Linguistic Studies, 15(2), 508-519. Doi: $10.17263 /$ jlls. 586175

\section{AUTHOR BIODATA}

Assoc. Dr. Idriz Metani was graduated from the Faculty of Phylology, University of Tirana, Albania. Actually he is a Professor of Albanian Language Lexicology and Linguistics History in the Language Department at the Faculty of History and Philology, University of Tirana. He is interested in lexical and interpretative semantics, having published many articles even abroad in this field. In collaboration with other scholars, he has also created many Albanian Language school textbooks for pre university education. His mail id is idrizmetani@yahoo.com.

Sidita Dano (Hoxhiq) is doing PhD and was graduated from the Faculty of Foreign Languages, University of Tirana, Albania. Currently, she is a lecturer at the Department of English, in the Faculty of Foreign Languages, University of Tirana, since 2008. She is interested in stylistics and literary studies, as well as comparative studies of Albanian and English textbooks. Her mail id is sidita21@yahoo.com.

${ }^{i}$ By realie is meant everything that lives in the outside world: objects, spirits and phenomena in nature, in society and in human thought. Realie is concrete when it is perceived by our senses, for example: bread, son, gold, mother, etc. and abstract, when perceived mentally or intellectually, eg: beauty, good fortune, happiness, misery, etc.

ii That something of reality, that the word has the ability to denote, can be a reality, i.e. thing, spiritual, phenomenon, feature, action, manner, number, relation, etc.

${ }^{i}$ B By realie is meant everything that lives in the outside world: objects, spirits and phenomena in nature, in society and in human thought. Realie is concrete when it is perceived by our senses, for example: bread, son, gold, mother, etc. and abstract, when perceived mentally or intellectually, eg: beauty, good fortune, happiness, misery, etc.

iii That something of reality, that the word has the ability to denote, can be a reality, i.e. thing, spiritual, phenomenon, feature, action, manner, number, relation, etc.

${ }^{i v}$ The object of our observation are today's textbooks of the Albanian language of pre-university education and specifically: Rita Petro, Dhurata Shehri, Natasha Pepivani, Gjuha shqipe 2, Albas Publishing House, Tirana, 2016; Rita Petro, Dhurata Shehri, Natasha Pepivani, Gjuha Shqipe 3, Albas Publishing House, Tirana, 2017, Rita Petro, Dhurata Shehri, Natasha Pepivani, Gjuha Shqipe 4, Albas Publishing House, Tirana, 2018, Rita Petro, Natasha Pepivani, Dhurata Shehri, Gjuha shqipe 5, Shtëpia botuese Albas, Tirana, 2019, Rita Petro, Lili Sula, Natasha Pepivani, Adelina Çerpia, Aljula Jubani, Idriz Metani, Gjuha shqipe 6, Shtëpia botuese Albas, Tirana, 2015, Rita Petro, Lili Sula, Aljula Jubani, Idriz Metani, Adelina Çerpia, Anila Çepani, Gjuha shqipe 7, Albas Publishing House, Tirana, 2016, Rita Petro, Lili Sula, Aljula Jubani, Idriz Metani, Adelina Çerpia, Anila Çepani, Gjuha shqipe 8, Albas Publishing House, Tirana, 2017, Rita Petro, Lili Sula, Aljula Jubani, Idriz Metani, Adelina Çerpia, Anila Çepani, Gjuha shqipe 9, Albas Publishing House, Tirana, 2018. 
${ }^{\mathrm{v}}$ If we take a quick look at the history of the Albanian curriculum for pre-university education, we will notice that it has known so far, in our opinion, at least six series of texts related to six different periods of its development: a) texts belonging to the period before the 40s of the XX century, b) texts belonging to the period after the 40 s to the 80 s of the XX century, c) texts belonging to the 80s-90s of the 20th century, d) texts drafted after the years 90 to 2004, e) texts drafted after 2004 until 2014, f) texts drafted from 2015 until today.

${ }^{v i}$ The number of literary and non-literary parts present in today's Albanian language textbooks of Albanian preuniversity education exceeds the figure 400 , of which more than half or $60 \%$ are parts containing language units unknown to students, and about 160 parts or almost $40 \%$ of them have no vocabulary unknown to students.

viiIdriz Metani, Rreth shpjegimit të fjalëve të panjohura për nxënësit në tekstet e gjuhës shqipe të arsimit parauniversitar, Studime albanologjike, I, Tiranë, 2011, p.99-110.

viii Pepa. S - Logu. B (1998), Zhvillimi i fjalorit-një komponent bazë në ligjërimin e nxënësve, Gjuha dhe ligjërimi në shkollë, Studime shqiptare 10.

${ }^{\text {ix }}$ According to the table, 416 words unknown to students are explained by description, 260 of them are explained by synonymy, 91 of them are explained by paraphrasing, while 86 words are explained by definition. 